\title{
Post-stroke psychosis: how long should we treat?
}

\section{Psicose após acidente vascular cerebral: até quando devemos tratar?}

\author{
Maria do Céu Ferreira, ${ }^{1}$ Célia Machado, ${ }^{2}$ Beatriz Santos, ${ }^{1}$ Álvaro Machado ${ }^{2}$
}

\begin{abstract}
Objective: To describe a rare case of a patient who developed psychotic symptoms after a right stroke that disappeared with antipsychotic treatment, but appears to need low-dose maintenance antipsychotic therapy.

Case description: A 65-year-old man presented at the psychiatric emergency service with a history of persistent delusional jealousy, visual illusions and agitation with onset about 1 month after a right posterior cerebral artery ischemic stroke. These symptoms only disappeared with therapeutic dosages of an antipsychotic drug ( $3 \mathrm{mg} /$ day of risperidone). At 2-year follow-up, he no longer had delusional activity and the antipsychotic treatment was gradually discontinued over the following year. However, 1 week after full cessation, the patient once more became agitated and suspicious and was put back on risperidone at $0.25 \mathrm{mg} /$ day, resulting in rapid clinical remission. One year after the return to low-dose risperidone, the patient's psychopathology is still under control and he is free from psychotic symptoms.

Comments: Psychosis is a relatively rare complication after stroke. To our knowledge, no cases of post-stroke psychosis that apparently require continuous low-dose antipsychotic treatment have been reported to date. Our case suggests that low-dose maintenance antipsychotic therapy may be needed for certain patients with post-stroke psychosis, especially for those with risk factors and non-acute onset.
\end{abstract}

Keywords: Psychosis, stroke, antipsychotic treatment.

\section{Resumo}

Objetivo: Descrever o caso raro de um paciente que desenvolveu sintomas psicóticos após um acidente vascular cerebral (AVC) no nível do hemisfério direito que remitiram com tratamento antipsicótico, mas parece precisar de uma terapêutica de manutenção com antipsicótico em baixa dosagem.

Descrição de caso: Um homem de 65 anos apresentou-se no serviço de urgência psiquiátrica por um quadro persistente de delírio de ciúmes, ilusões visuais e agitação com início cerca de 1 mês após AVC isquêmico no nível da artéria cerebral posterior direita. Esses sintomas só desapareceram com doses terapêuticas de antipsicótico (risperidona $3 \mathrm{mg} / \mathrm{dia}$ ). Após 2 anos de seguimento, o paciente não mais apresentava atividade delirante, e o tratamento antipsicótico foi progressivamente descontinuado durante o ano seguinte. No entanto, 1 semana após a suspensão total, o paciente começou a ficar agitado e desconfiado, tendo-se reiniciado a risperidona $0,25 \mathrm{mg} / \mathrm{dia}$, com rápida remissão clínica. O paciente está medicado com esta baixa dose de antipsicótico há um ano, permanecendo psicopatologicamente compensado e sem sintomas psicóticos.

Comentários: A psicose é uma complicação relativamente rara após AVC. Segundo nosso conhecimento, não há casos descritos até ao momento de psicose após AVC que, aparentemente, requerem uma dose baixa contínua de antipsicótico. Nosso caso sugere que uma terapêutica de manutenção com antipsicótico em baixa dosagem pode ser necessária para determinados pacientes com psicose após AVC, especialmente para aqueles com fatores de risco e início não agudo dos sintomas.

Descritores: Psicose, acidente vascular cerebral, tratamento antipsicótico.

\footnotetext{
${ }^{1}$ Serviço de Psiquiatria, Hospital de Braga, Braga, Portugal. ${ }^{2}$ Serviço de Neurologia, Hospital de Braga, Braga, Portugal. Financial support: none.

Submitted Dec 16 2015, accepted for publication Jan 242017.

Suggested citation: Ferreira MC, Machado C, Santos B, Machado A. Post-stroke psychosis: how long should we treat? Trends Psychiatry Psychother. 2017;39(2):144-146. http://dx.doi.org/10.1590/2237-6089-2015-0090
} 


\section{Introduction}

The objective of this paper was to describe the case of a patient who developed persistent delusional jealousy after a right stroke that disappeared with antipsychotic treatment, but appears to need low-dose maintenance antipsychotic therapy.

\section{Case description}

Written informed consent was obtained from the patient for publication of this case report.

A 65-year-old man presented at a psychiatric emergency service with a history of persistent delusional jealousy, visual illusions, and agitation that had onset about 1 month after a right posterior cerebral artery ischemic stroke and had a duration of 6 months. The patient is married and lives with his wife and daughter. $\mathrm{He}$ is totally independent in all areas of activities of daily living.

He believed that his wife was unfaithful, although she denied this persistently, was aggressive and threatened her, smelled her clothes, and attempted to control her. Additionally, he thought that his wife had hidden men in the room, so he looked for them everywhere and said that he could see their shadows at home, which in fact corresponded to objects such as curtains or chairs. Sometimes when people went to his house, he thought that they were his wife's lovers and became physically aggressive towards male visitors.

The patient was treated for about 2 months with 2 $\mathrm{mg} /$ day of risperidone and $30 \mathrm{mg} /$ day of mianserin, without clinical improvement. His medical history included hypertension, dyslipidemia, type 2 diabetes mellitus, right posterior cerebral artery ischemic stroke, and alcohol abuse since he was 30 years old (without psychiatric follow-up), until the point at which he suffered the ischemic stroke. He had been totally abstinent for 6 months and did not exhibit alcohol withdrawal symptoms.

There was no known family history of psychiatric illness. The psychiatric assessment showed no alteration in consciousness, psychomotor agitation with verbal aggressive behavior, neutral mood, delusional jealousy, visual illusions, paranoid and jealous personality traits, and absence of insight.

Neurological examination demonstrated left lower quadrantanopia and was otherwise normal, without evidence of cognitive impairment (normal Mini Mental State Examination score). Results of analytical studies, serological tests, and toxicology screen were all normal. Blood alcohol content was negative.
Magnetic resonance imaging (MRI) of the brain showed global atrophy and detected no recent ischemic lesions in the right temporo-occipital or bilateral frontoparietal subcortical regions.

The patient was admitted to the psychiatric service and treated with $3 \mathrm{mg} /$ day of risperidone and $1 \mathrm{mg} /$ day of lorazepam with complete resolution of delusional ideation over the next 3 weeks.

He was referred to an outpatient psychiatric service and his psychopathology remained under control using the same psychiatric medication. Two years later, the risperidone dose was progressively reduced to $0.5 \mathrm{mg} /$ day, with no psychiatric deterioration. At 3-year followup, he still had no delusional activity and the antipsychotic treatment was discontinued. However, 1 week later the patient became more agitated and suspicious about his wife and was put back on risperidone at $0.25 \mathrm{mg} /$ day, with rapid clinical remission.

One year after resumption of low dosage risperidone, the patient's psychopathology is still under control and he is free from psychotic symptoms.

\section{Comments}

This clinical case has some peculiarities that differentiate it from other cases of post-stroke psychosis reported in the literature. For example, with regard to onset, in our patient psychotic symptoms occurred approximately 1 month after a right posterior cerebral artery stroke, whereas in most of the cases reported psychotic symptoms appeared within 1 week of right stroke. Some cases of delayed-onset poststroke psychosis were reported recently that could be associated with epilepsy. ${ }^{1}$

We suspected that these psychotic symptoms were related to the prior stroke, because other possible causes were excluded, specifically alcohol-related clinical conditions such as intoxication, withdrawal, delirium tremens, Wermicke-Korskoff syndrome, alcoholic hallucinosis, and alcoholic dementia.

With relation to the course and duration of treatment, this patient developed a persistent delusional disorder that only disappears with therapeutic doses of antipsychotics and apparently requires continuous low-dose antipsychotic treatment. Nevertheless, in general, psychotic symptoms respond well to treatment with antipsychotic drugs and usually persist for a short period of time, without a need for long-term antipsychotic treatment. In the rare cases of non-acute onset, psychotic symptoms appear to be persistent and overall remission is difficult to achieve 
even on long-term antipsychotic treatment. ${ }^{1}$ To our knowledge, no cases of post-stroke psychosis that need low-dose antipsychotic maintenance treatment have been reported to date.

In fact, the available literature is not clear on the duration of antipsychotic treatment or on whether there are differences between early and late-onset psychosis after cerebrovascular infarction.

This case also has other interesting peculiarities: a history of alcohol abuse, paranoid and jealous personality traits, and MRI showing global brain atrophy, right temporo-occipital infarction, and no recent focal ischemic lesions in bilateral frontoparietal subcortical regions. These findings are important because prior studies suggest that preexisting subcortical atrophy, mental health problems, and also the lesion site in the right hemisphere can be important risk factors for poststroke psychosis. 2 Injuries to frontotemporoparietal regions can lead to fronto-subcortical disconnection and a variety of neuropsychiatric symptoms. ${ }^{3}$ With relation to jealous delusions, there is no specific location, but some areas do seem to be associated, including the frontal, posterior parietal, striatal, and thalamic regions. ${ }^{4}$

Recent studies suggest that positive symptoms are related to a reduction in cognitive inhibition and left hemisphere overactivity after loss of right-sided influences. 3,5 Additionally, involvement of the right inferior frontal lobe and superior longitudinal fasciculus seems to be a risk factor for development of psychosis, possibly because it causes impaired anatomical connectivity, potentiating symptom-associated neural overactivity within the disconnected cortex. ${ }^{3}$

Our case suggests that continuous low-dose antipsychotic therapy may be needed for certain patients with post-stroke psychosis, especially for those with risk factors and non-acute onset.

Since there are few reported cases covering this issue, further studies are needed to try to identify the profile of individuals who develop psychosis and to determine the ideal duration of antipsychotic treatment in these cases.

\section{Disclosure}

No conflicts of interest declared concerning the publication of this article.

\section{References}

1. Barboza RB, De Freitas GR, Tovar-Moll F, Fontenelle LF. Delayedonset post-stroke delusional disorder: a case report. Behav Neurol. 2013;27:287-91.

2. McMurtray A, Tseng B, Diaz N, Chung J, Mehta B, Saito E. Acute psychosis associated with subcortical stroke: comparison between basal ganglia and mid-brain lesions. Case Rep Neurol Med. 2014;2014:428425.

3. Devine MJ, Bentley P, Jones B, Hotton G, Greenwood RJ, Jenkins IH, et al. The role of the right inferior frontal gyrus in the pathogenesis of post-stroke psychosis. J Neurol. 2014;261:600-3.

4. Rocha S, Pinho J, Ferreira, C, Machado A. Othello syndrome after cerebrovascular infarction. J Neuropsychiatry Clin Neurosci. 2014;26:E1-2.

5. Devinsky O. Delusional misidentifications and duplications: right brain lesions, left brain delusions. Neurology. 2009;72:80-7.

\section{Correspondence:}

Maria do Céu Ferreira

Serviço de Psiquiatria, Hospital de Braga

Sete Fontes, São Victor

4710-243 - Braga - Portugal

Tel.: +351962592569

E-mail: ceu@live.com.pt 